\title{
Pimelea cremnophila (Thymelaeaceae), a new species from the New England Tablelands escarpment of northern New South Wales
}

\author{
Lachlan M. Copeland and Ian R.H. Telford
}

Botany, Centre for Ecology, Evolution and Systematics, The University of New England, Armidale, NSW 2351

\begin{abstract}
Pimelea cremnophila L.M.Copel. \& I.Telford, a rare new species endemic to the Macleay Gorges east of Walcha, is described. Notes are given on its distribution, habitat and conservation status. Although all plants are known from a conservation reserve the species is considered to be endangered due to its restricted distribution and small population size.
\end{abstract}

\section{Introduction}

The gorge country of the eastern escarpment of the New England Tableland is well known as a 'hot spot' for endemism. Narrowly endemic taxa in the Macleay and Guy Fawkes River gorges include Hakea fraseri, Phebalium squamulosum subsp. verrucosum, Leucopogon trichostylus, Zieria floydii and Bertya ingramii. Other taxa thought to be endemic to the area include undescribed members of Westringia, Persoonia, Acalypha, Zieria, Callistemon, Eucalyptus, Leionema and Olearia (Briggs \& Leigh 1996; Copeland 1997). Recent fieldwork in Oxley Wild Rivers National Park has yielded a species of Pimelea which did not fit any currently known taxa in the treatments of Threlfall (1983), Rye (1990) and Harden (1990). An examination of Pimelea specimens held in CANB, NSW and NE also supported the recognition of the Macleay Gorges Pimelea as distinct (herbarium abbreviations follow Holmgren et al. 1990). This paper describes the new species and gives notes on its distribution, habitat and conservation status.

Pimelea cremnophila L.M.Copel. \& I.Telford sp. nov.

P. umbratica similis sed indumento foliari caulinoque longiore densioreque et filamentis staminum distinctis differt.

Type: New South Wales: Northern Tablelands: Oxley Wild Rivers National Park, c. $40 \mathrm{~km}$ ENE of Walcha, $30^{\circ} 55^{\prime} \mathrm{S}, 151^{\circ} 52^{\prime} \mathrm{E}$, L.M. Copeland 3816, I.R. Telford \& P.J. Lupica, 13 Oct 2004 (holo NSW; iso BRI, CANB, CHR, HO, K, MEL, MO, NE). (Specific locality details withheld for conservation purposes).

Erect shrub to $2.5 \mathrm{~m}$ tall. Stems red-brown, hirsute with strigose white antrorse hairs to 3 $\mathrm{mm}$ long, glabrescent with age. Leaves opposite, petiolate; petioles c. $1 \mathrm{~mm}$ long, densely 
hairy; lamina narrow-elliptic to narrow-ovate, acute, 10-37 mm long, 2.5-6 mm wide, secondary venation indistinct, the adaxial surface glabrous or sparsely hairy mainly along the midvein, the abaxial surface paler and hirsute with scattered white, strigose hairs, the hairs denser and longer, to $2.5 \mathrm{~mm}$ long, on the margins. Inflorescences axillary or terminal, extending up to 15 nodes below shoot apex,1-4 flowered, condensed racemes 2-3 mm long; peduncle c. $1 \mathrm{~mm}$ long, strigose; bracts leaf-like, c. 2.5-5 mm long, caducous. Flowers functionally male, bisexual or functionally female; subsessile. Hypanthium antrorse hairy outside, glabrous inside, greenish-white; sepals 4, narrowovate. Male flowers with hypanthium 6-8 mm long; sepals 3-4 $\mathrm{mm}$ long; stamens 2, rarely 3 , inserted near summit of hypanthium; filaments c. $1 \mathrm{~mm}$ long; anthers narrowoblong, c. $1.7 \mathrm{~mm}$ long; pistillode c. $1 \mathrm{~mm}$ long. Bisexual flowers protandrous, with hypanthium 4-6.5 mm long; sepals 3-4 mm long; stamens similar to male flowers; ovary c. $1.5 \mathrm{~mm}$ long, with erect hairs at apex; style eventually exserted; stigma brushlike. Female flowers with hypanthium 3-4.5 mm long, circumscissile c. $1 \mathrm{~mm}$ below sepal attachment; sepals 1.5-2.5 mm long; staminodes minute; gynoecium similar to bisexual flowers. Fruit dry, ovoid, enclosed in the persistent base of the hypanthium, pale green. Seed ovoid, 3-3.5 mm long, c. $2 \mathrm{~mm}$ wide, with minute longitudinal, foveate furrows, red-brown (Fig.1).

Additional specimens examined: New South Wales: Northern Tablelands: Oxley Wild Rivers National Park: c. $40 \mathrm{~km}$ ENE of Walcha, 30 $55^{\prime} \mathrm{S}, 151^{\circ} 52^{\prime} \mathrm{E}$, L.M. Copeland 3444 \& P. Lupica, 24 Oct 2002, (BRI, CANB, MEL, NSW, NE); c. $40 \mathrm{~km}$ ENE of Walcha, 30 $55^{\prime} \mathrm{S}, 151^{\circ} 52^{\prime} \mathrm{E}$, L.M. Copeland 3608 \& S. Doak, 8 Oct 2003, (CANB, MEL, NE, NSW); rim of gorge of Spring Ck., c. $38 \mathrm{~km}$ E of Walcha, $30^{\circ} 55^{\prime} \mathrm{S}, 151^{\circ} 51^{\prime} \mathrm{E}$, L.M. Copeland 3735, J.J. Bruhl \& I.R. Telford, 4 May 2004, (BRI, CANB, NSW, NE); c. 38 km ENE of Walcha, 3055'S, 151 ${ }^{\circ} 51^{\prime}$ E, L.M. Copeland 3819, I.R. Telford \& P.J. Lupica, 13 Oct 2004, (AD, NSW, NE); c. $37 \mathrm{~km}$ ENE of Walcha, edge of gorge of Redmans Ck, 30 56'S, 151 ${ }^{\circ} 51^{\prime} \mathrm{E}$, L.M. Copeland 3822, I.R. Telford \& P.J. Lupica, 13 Oct 2004, (AD, AK, BRI, CANB, CHR, HO, MEL, NSW, NE). (Specific locality details of all specimens withheld for conservation purposes).

Distribution: apparently confined to gorge rims in the southern part of Oxley Wild Rivers National Park, approximately $40 \mathrm{~km}$ E of Walcha. Several small populations are scattered along a $5 \mathrm{~km}$ stretch of gorge rim. A large area of similar habitat exists within the park and further searches of this area of gorge rim could potentially yield additional populations.

Habitat: all plants observed grow in a shallow, skeletal loam over metasediments on exposed cliff tops or more sheltered cliff-side sites with south-westerly to southeasterly aspects. Altitude ranges from 1050-1090 m. Associated species include Allocasuarina littoralis, Eucalyptus retinens, E. campanulata, Acacia blakei subsp. diphylla, Maytenus silvestris, Prostanthera rhombea, Dodonaea rhombifolia, Astrotricha longifolia, Ozothamnus obcordatus, Persoonia media, Callistemon sp. nov., Correa reflexa var. reflexa, Lepidosperma elatius s.l., L. laterale, Rhodanthe sp. nov. and Notodanthonia longifolia.

Flowering: flowers have only been observed in early to mid October, but the presence of unopened floral buds and young fruits on specimens suggests that the species is likely to flower throughout spring.

Conservation status: the species is currently known from fewer than 100 individuals and relatively few juveniles have been observed. Potential threats include an inappropriate fire regime and grazing by feral goats. Several mature individuals appeared to die during 

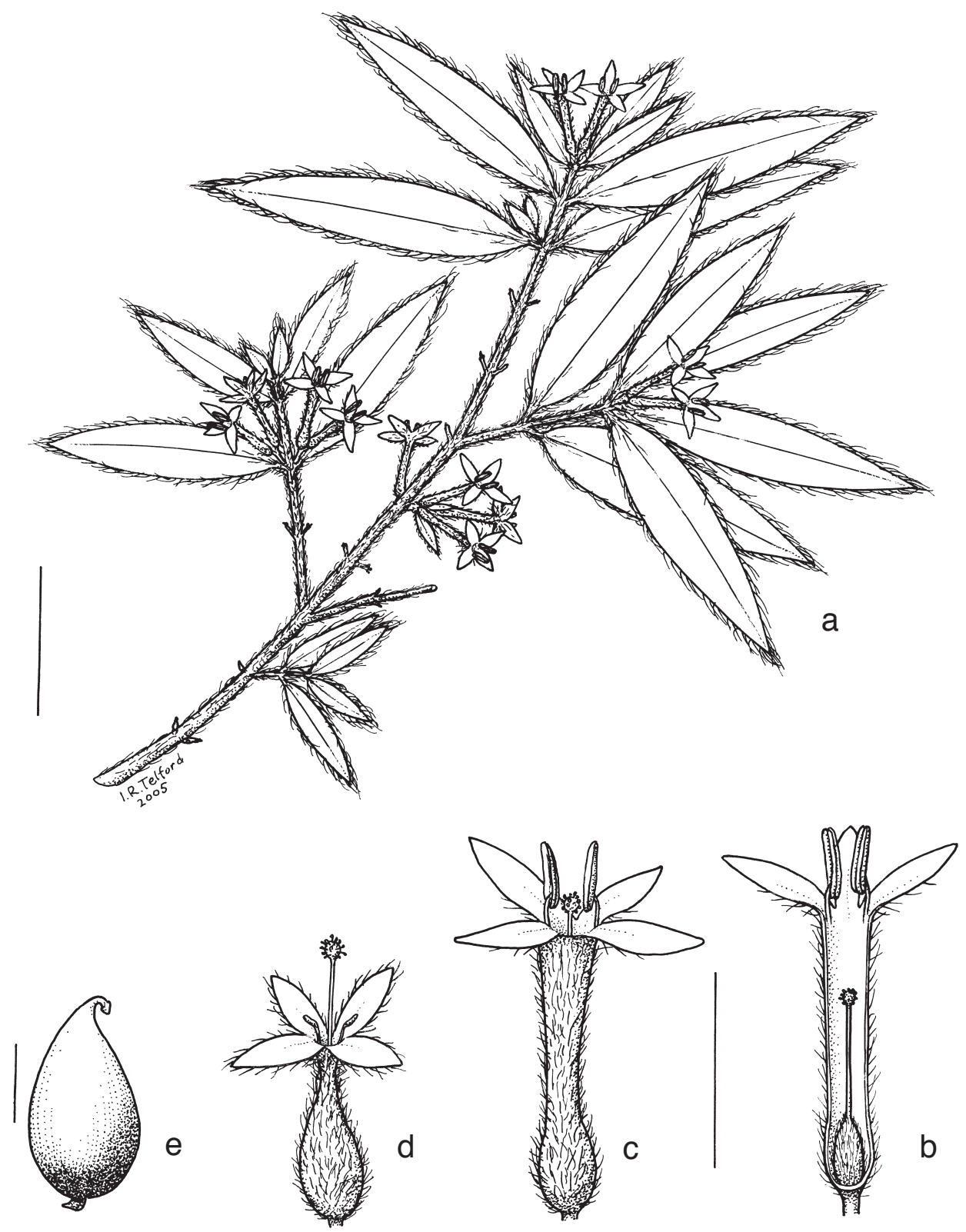

Fig. 1. Pimelea cremnophila $\mathbf{a}$, flowering branch; $\mathbf{b}$, bisexual flower prior to elongation of style, with part of hypanthium and one sepal removed; c, bisexual flower; d, functionally female flower; e, seed. Scale bar: $\mathrm{a}=10 \mathrm{~mm}$; $\mathrm{b}-\mathrm{d}=5 \mathrm{~mm}$; e $=1 \mathrm{~mm}$. (a, b, e, from L.M. Copeland 3608 \& S. Doak; c, d, from L.M. Copeland 3816, I.R. Telford \& P. Lupica) 


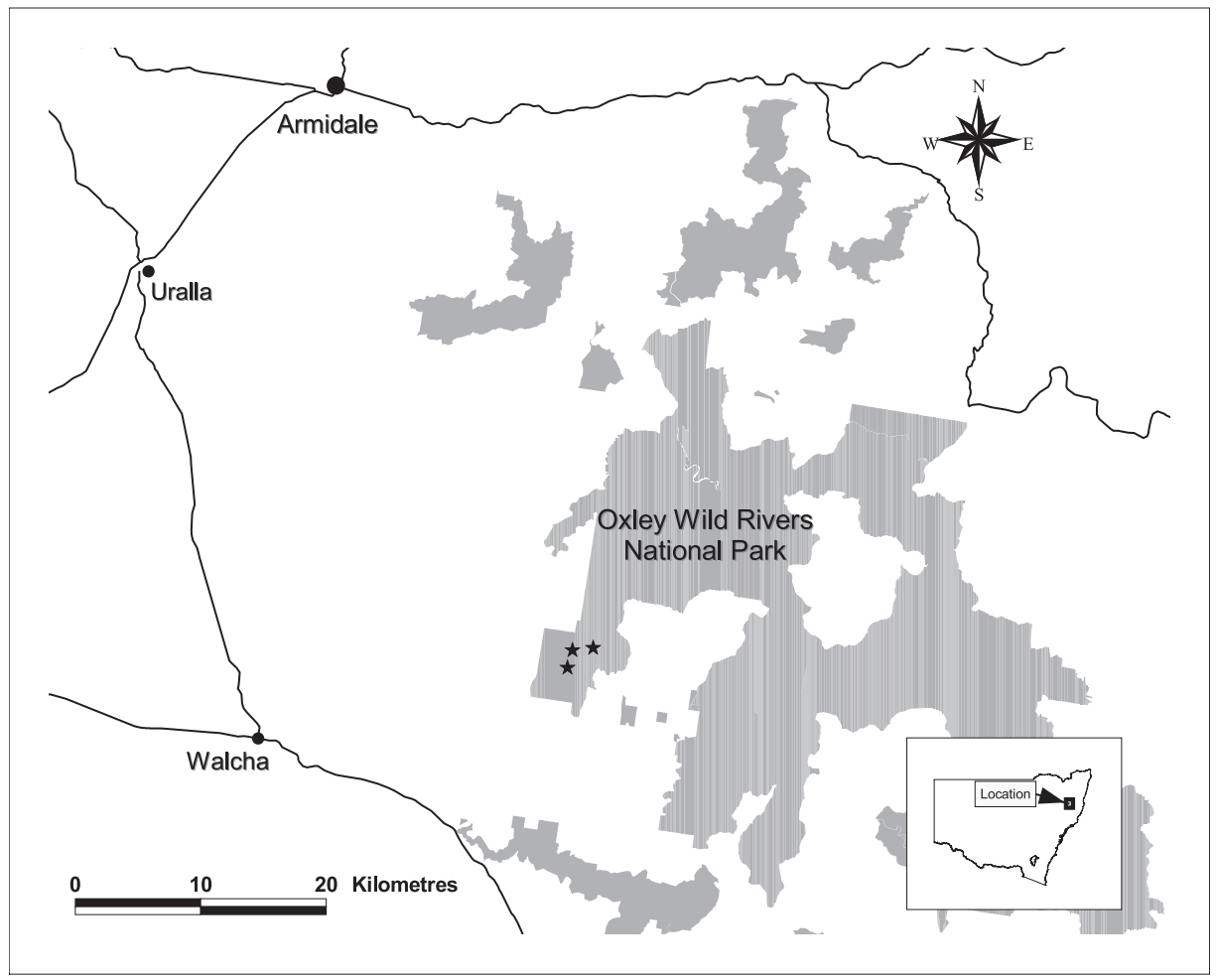

Fig. 2. The distribution of Pimelea cremnophila (denoted by $\star$ ) in northern New South Wales.

the period 2002-2003, presumably due to the extreme drought conditions endured at the time. Although all known plants are reserved in Oxley Wild Rivers National Park, the species should still be considered endangered due to its highly restricted distribution, small population size and the potential threats. A ROTAP code of 2ECit is recommended following the criteria of Briggs \& Leigh (1996).

Etymology: the specific epithet cremnophila is derived from the Greek cremnos (cliff) and philos (loving), in reference to its habitat.

Comparison with similar species: Pimelea cremnophila belongs to section Epallage (Endl.) Benth. and appears to be most similar to P. umbratica. It differs from P. umbratica by its longer, denser indumentum, less prominent secondary leaf venation, predominantly axillary inflorescences, and smaller anthers on distinct filaments (Table 1).

Sexuality in sect. Epallage requires further study. Threlfall (1983) stated that in P. umbratica, male, female and bisexual flowers may occur on the same individual. However, Threlfall included P. leptospermoides under P. umbratica and did not cite which specimens had been studied for that observation. Rye (1990) claimed P. umbratica has bisexual and female flowers. We have observed apparently functionally male (with pistillodes) and functionally female (with staminodes) flowers on the same plant. In P. cremnophila, plants appear to be polygamous, with functionally male and bisexual flowers on the same plants and only functionally female on others.

Note that in Harden (1990) the description of P. umbratica follows Threlfall (1983) with $P$. leptospermoides (a central Queensland serpentinite endemic) included in the circumscription. The leaves of $P$. leptospermoides are alternate while those of P. umbratica are in fact opposite. 
Table 1. A comparison of the distinguishing features between Pimelea cremnophila and $P$. umbratica.

Character
Secondary venation
Secondary venation angle
Inflorescence
Bisexual flower hypanthium length
Bisexual flower sepal length
Stamens
Anther length
Seed colour

\section{P. cremnophila}

obscure

$25-35^{\circ}$

mostly axillary

$4-6.5 \mathrm{~mm}$

3-4 mm

filaments present

$1.7 \mathrm{~mm}$

red-brown

\author{
P. umbratica \\ prominent \\ $40-50^{\circ}$ \\ mostly terminal \\ 5-7.5 mm \\ 2-2.5 mm \\ anthers subsessile \\ 2-2.5 mm \\ black
}

\section{Acknowledgments}

We are grateful to Sam Doak and Patrick Lupica, rangers from the NSW National Parks and Wildlife Service, for their assistance in the field. Patrick Lupica is also thanked for producing the distribution map. Jeremy Bruhl also assisted in the field and gave constructive comments on the manuscript. We would like to thank Peter Wilson for assisting with the Latin diagnosis. Directors of CANB, NSW and NE are also thanked for allowing access to specimens held within their herbaria.

\section{References}

Briggs JD \& Leigh JH (1996) Rare or Threatened Australian Plants, revised edition. (CSIRO Publishing: Collingwood)

Copeland LM (1997) Rare or Threatened Plants (ROTAPs) occurring in Oxley Wild Rivers National Park. Unpublished report produced for the NSW National Parks and Wildlife Service.

Harden GJ (1990) Thymelaeaceae. Pp. 375-387 in Harden GJ (ed.) Flora of New South Wales, vol. 1. (New South Wales University Press: Kensington)

Holmgren PK, Holmgren NH \& Barnett LC (1990) Index Herbariorum 8th Edition. (New York Botanical Garden: New York)

Rye BL (1990) Thymelaeaceae. Pp. 122-215 in George AS (ed.) Flora of Australia, vol. 18. (Australian Government Publishing Service: Canberra)

Threlfall S (1983) The genus Pimelea (Thymelaeaceae) in eastern mainland Australia. Brunonia 5: 113-201. 